\title{
Hydrogeology of the Valley-Fill Aquifer in the Onondaga Trough, Onondaga County, New York
}

\section{In cooperation with the Onondaga Lake Cleanup Corporation and the Onondaga Lake Partnership}

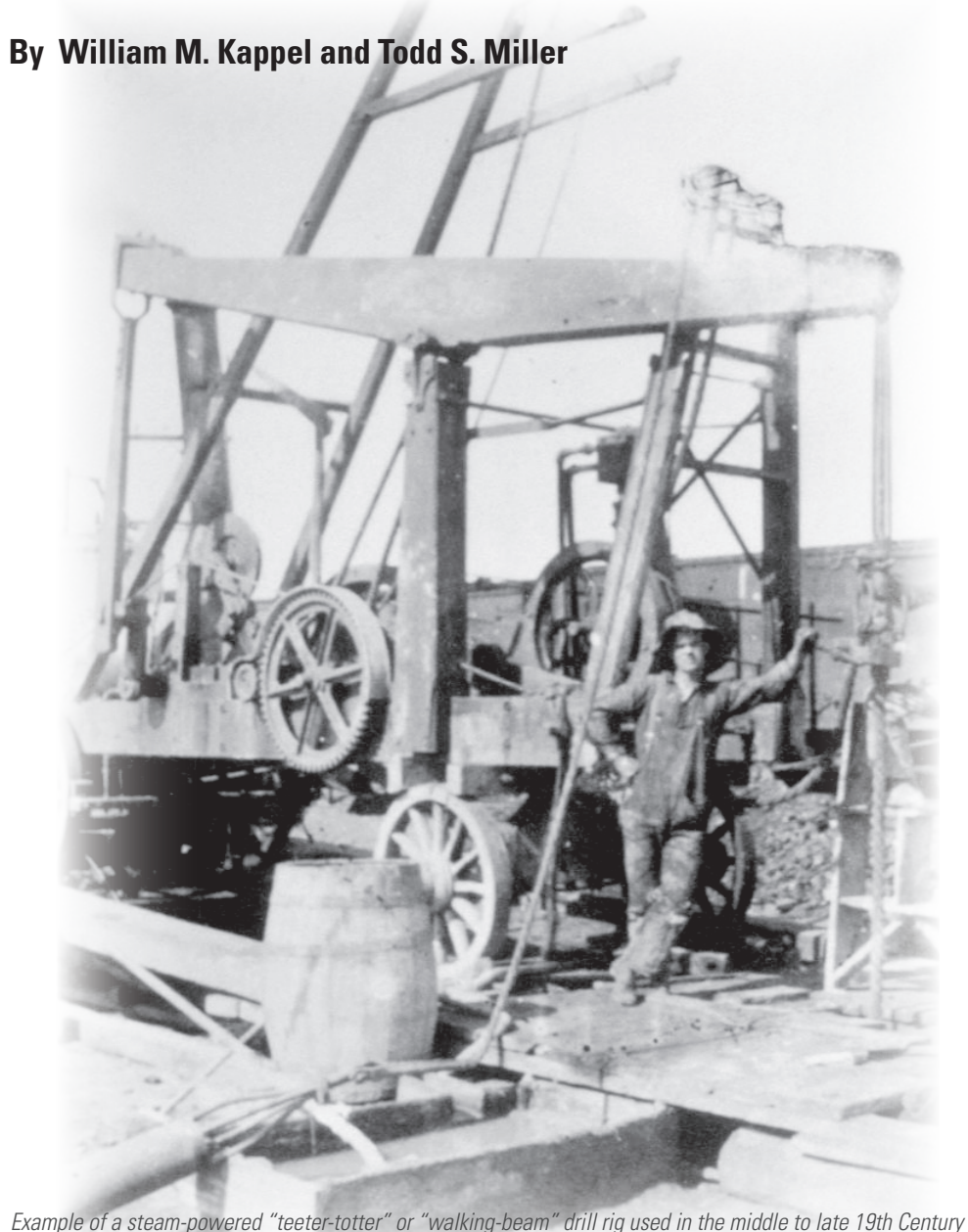

a steam-powered "teeter-totter" or "walking-beam" drill rig used in the middle to late 19th Century to drill through as much as 400 feet of unconsolidated sediments to obtain concentrated brine from the deep valley-fill deposits along the southern shore of Onondaga Lake, New York. (Courtesy of the Onondaga County Salt Museum.)
Continuing efforts to improve water quality in Onondaga Lake, New York and its tributaries require an understanding of how the natural, brine-filled aquifer in the Onondaga Trough (valley) affects the freshwater in Onondaga Lake. The city of Syracuse, locally known as "The Salt City," was built around the salt springs, which issued from a valley-fill aquifer that contains a highly concentrated brine (up to six times as salty as sea water), but little is known about the source of the brine, its movement within the glacial sediments that partly fill the Onondaga Trough, and the interaction of the aquifer and the lake. This report summarizes initial data-collection and analysis efforts in the 25-mile long Onondaga Trough that extends from near Tully, N.Y., to the outlet of Onondaga Lake and presents results of some initial chemical and geographic analyses that will lead to the development of a mathematical ground-water-flow model of the valley-fill aquifer.

\section{Introduction}

The U.S. Geological Survey (USGS), in cooperation with the Onondaga Lake Clean-up Corporation and Onondaga Lake Partnership, is currently (2005) developing a ground-waterflow model of the unconsolidated deposits (valley-fill aquifer) in the Onondaga Trough to determine the direction and rate of flow of brine in the aquifer and its interaction with Onondaga Lake. The purpose of this report is to describe the geologic and water-quality data that are being used to develop conceptual and mathematical models of the aquifer.

Geologic Data Collection - The primary source of geologic data are logs of test holes drilled at construction sites throughout the valley for buildings, roads, bridges, public utilities, and other projects. Many of these projects are concentrated in the urban area of Syracuse and along major highways. Test holes outside Syracuse are scant and the data are generally less detailed because only limited geologic data are required for most smallscale construction in rural areas. Test-hole logs (descriptions of materials penetrated) provide data on stratigraphy (layering of the glacial sediment), soil properties (permeability, compactness, texture, and color), and ground-water levels encountered during drilling. Test holes can be drilled into unconsolidated material only or they may penetrate into bedrock. 
Most of the test-hole logs used in this study were provided by the New York State Department of Transportation, especially those from the Interstate corridors (I-81, I-90, I-481, and I-690) and the many road- and bridge-construction projects throughout the study area. Additional logs of local projects (public buildings, utility corridors, and road construction) were provided by the city of Syracuse and Onondaga County, and private construction projects (large buildings, office complexes, and malls) provided others.

Supplemental information in rural areas was obtained from hydrogeologic data obtained from local ground-water studies and from a statewide, wellregistration program established in 2000 by the New York State Department of Environmental Conservation (NYSDEC). Additional stratigraphic data for the valley-fill deposits were obtained from 12 deep test holes drilled for the USGS between 2002 and 2004.

Geologic Data Analysis - A bedrock geologic section along the thalweg (deepest part) of the valley was developed to depict the general southward dip of the bedrock ( 40 to 50 feet per mile) and the approximate location of these bedrock units along and beneath the valley walls and floor.

Geologic sections of unconsolidated materials were drawn across the Onondaga Valley, or a major tributary valley, where the available information was sufficient for geologic interpretation. A total of 17 geologic sections between the outlet of Onondaga Lake and the moraine at Tully, were drawn. These sections depict the configuration of the bedrock surface below the valley floor, as well as the layering within the unconsolidated deposits above the bedrock. Stratigraphic details are omitted where data were unavailable within part of a geologic section, and in these cases, the bedrock profile is approximated.

A longitudinal geologic section of the Onondaga Trough was drawn using six geologic sections that incorporates data from and between these sections into an approximation of the unconsolidated deposits along the thalweg of the valley.

Geographic Analysis of Data - The development of the ground-water-flow model of the Onondaga valley-fill aquifer will require the compilation and display of large amounts of data, such as a digital-elevation model (DEM) of land-surface elevation, depth to bedrock from test holes drilled throughout the valley, water-table elevations, and type and thickness of unconsolidated deposits. These data are managed through a geographic information system (GIS). Data analyzed in this GIS will be used during development and calibration of the ground-water-flow model.

Brine Analysis - The quality of brine was determined through analysis of water collected from test holes drilled for the USGS in 2002 and 2003. These data were needed to measure brine concentrations throughout the valley-fill aquifer and determine the origin of the brine. These data are to be incorporated into the hydrogeologic framework of the regional ground-water-flow model that is to represent the valley-fill aquifer in the Onondaga Trough.

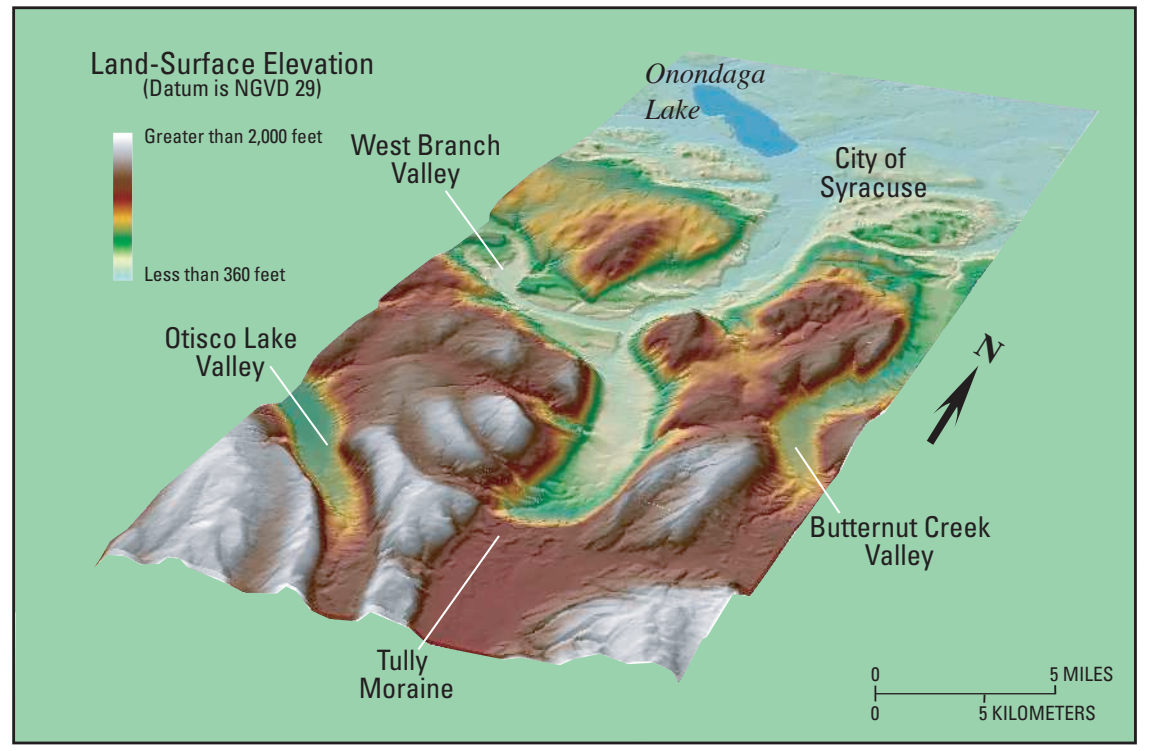

Figure 1. Oblique view of the land surface in and around the Onondaga Trough, as viewed from the southeast, looking northwest.

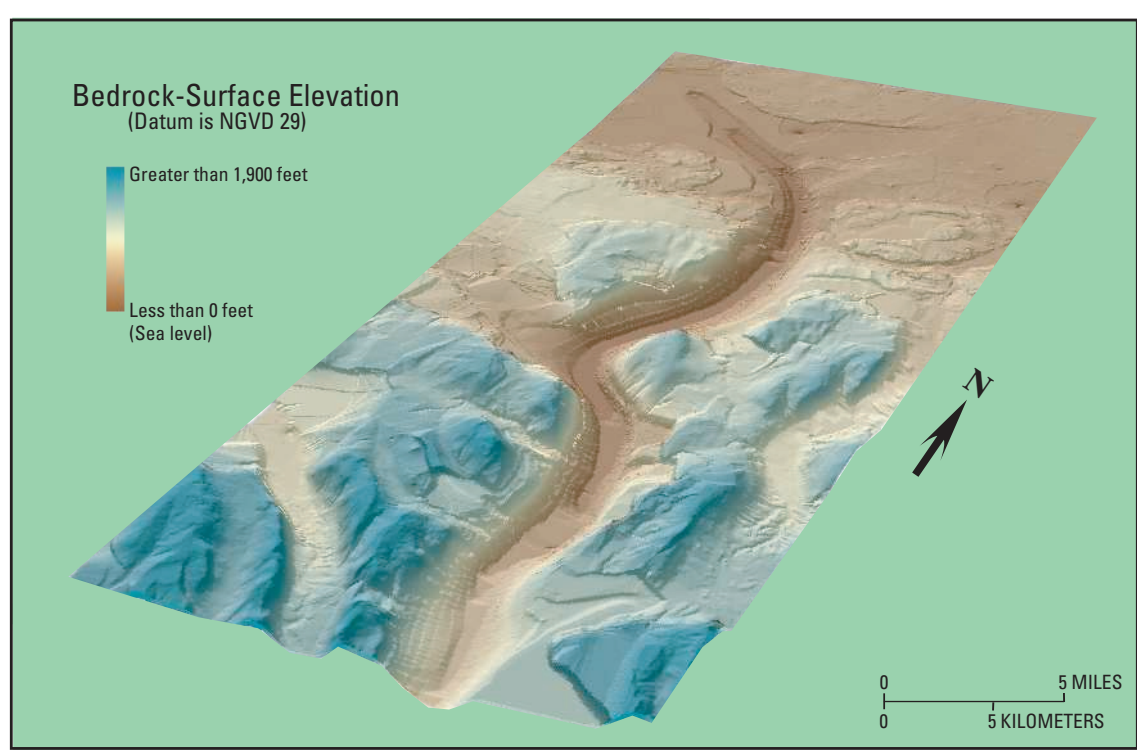

Figure 2. Oblique view of the bedrock surface in the Onondaga Trough, as viewed from the southeast, looking northwest. Data were obtained by subtracting test-hole elevation data from the 10-meter digital-elevation model of the land surface. Not enough data are available outside the Onondaga Trough for reliable interpretation of the bedrock surface in the upland areas or in adjacent valleys. 


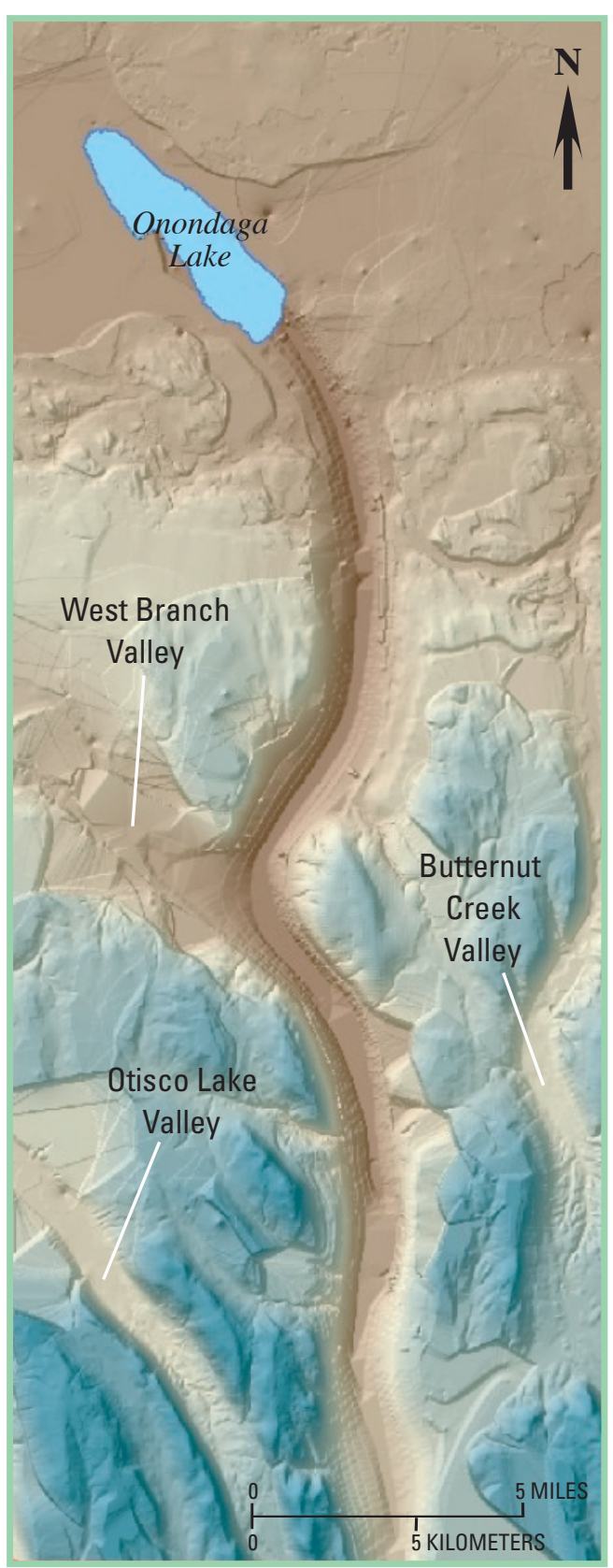

Figure 3. Onondaga Trough projected as a plan or "birds-eye" view.

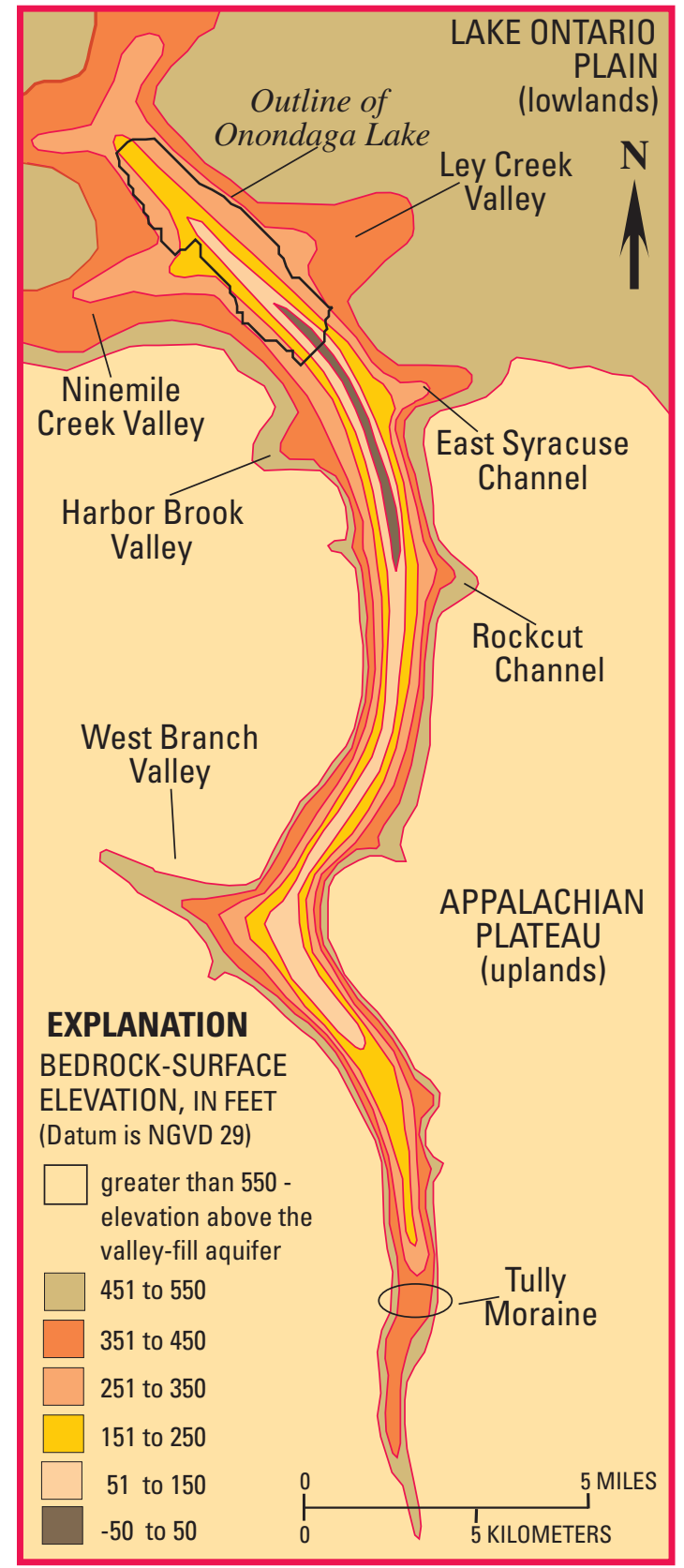

Figure 4. Elevation contours of the Onondaga Trough.

\section{GIS- Based Assessment of the Onondaga Trough}

Two initial products of the geographic information system (GIS) analysis are shaded-relief maps of (1) the land surface in the Syracuse area (fig. 1) and (2) the underlying bedrock surface (fig. 2) in the Onondaga Trough. The bedrocksurface map was generated by interpolating elevation data from test-hole logs and other data sources, and subtracting these values from the Digital Elevation Model (DEM) land-surfaceelevation value at each well location. The resulting dataset is to be directly applied to the groundwater-flow model to generate mathematical grids of the bedrock surface that will establish the hydrogeologic framework for model simulation.

The shaded-relief map in figure 1 was developed from the USGS 10-meter DEM of land-surface elevations. The elevation data were derived from various sources, including topographic maps and recent air and satellite imagery. The image for figure 1 was then rotated to provide an oblique view of the Onondaga Trough (as if the viewer were flying northwestward toward Syracuse from the southeast). The upland area to the south (in the white to brown shades) is the northern extent of the Appalachian Plateau. The dark green to light green colors indicate land-surface elevations that slope down to the Lake Ontario Plain - the plain is shown as the light blue area on the northern end of the image. The darker blue is Onondaga Lake.

The bedrock floor of the Onondaga Trough is depicted in figure 2 as if all the glacial sediments have been removed from the valley. Bedrockelevation data from the upland areas surrounding the Onondaga Creek, Otisco Lake, and Butternut Creek Valleys are insufficient to provide a reliable image of the surrounding bedrock surface on this map; therefore, the land outside the Onondaga Trough represents surface elevation, not bedrock elevation. 


\section{GENERALIZED BEDROCK GEOLOGIC SECTION - TULLY MORAINE TO ONONDAGA LAKE NEAR SYRACUSE}

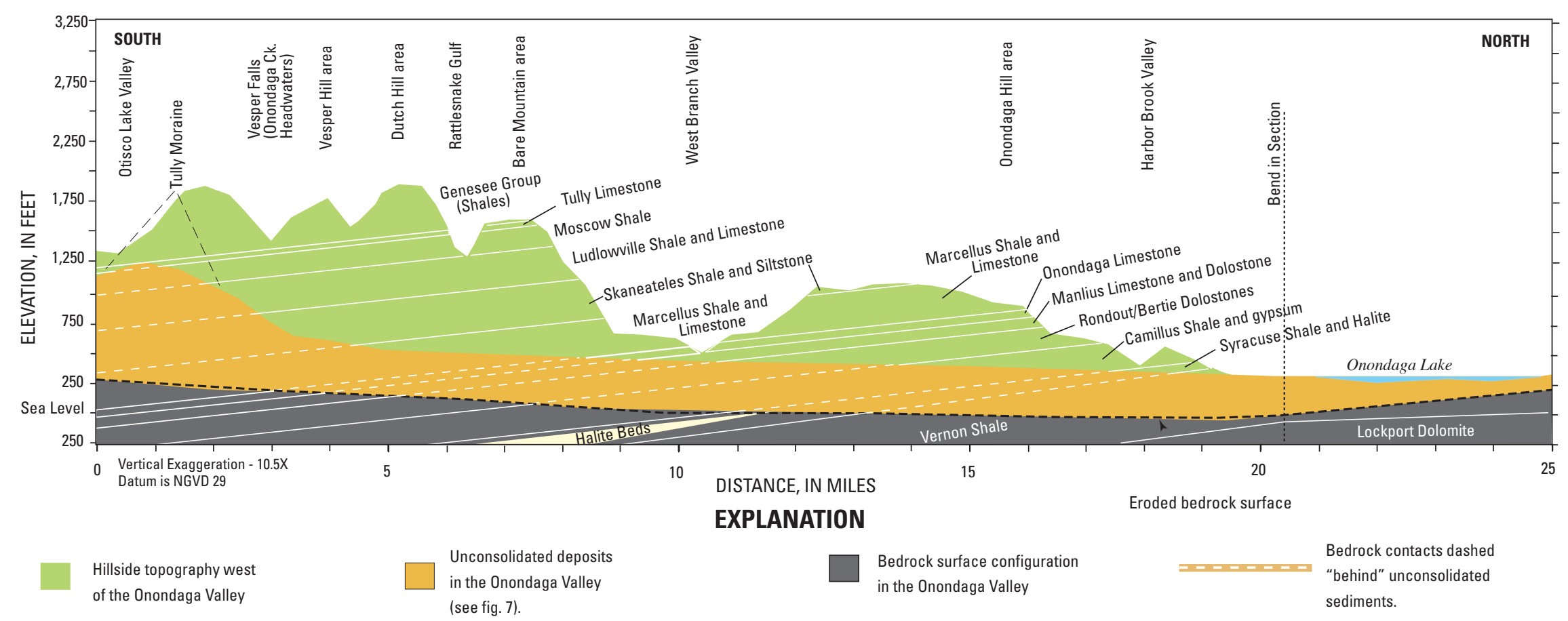

Figure 5. Geologic section along the thalweg of the Onondaga trough valley from the Tully Moraine to the Onondaga Lake outlet showing the generalized bedrock stratigraphic sequence.

A "birds-eye-view" of the bedrock-surface map shown in figure 2 is given in figure 3 , and a contoured representation of the bedrock surface of the Onondaga Trough is shown in figure 4 . Small, circular depressions and hills, mostly outside the main valley are shown in figure 3 . These features reflect individual bedrock

(well) elevations so widely scattered that the GIS process could not accurately link them to draw a representative bedrock surface in those areas.

The bedrock-surface elevations depicted in figure 4 range from mean sea level [National Geodetic Vertical Datum of 1929 (NGVD 29)] in the deepest part of this bedrock valley to greater than 550 feet on the hillsides to the south. The bedrock reaches elevations greater than 1,400 feet along ridge tops on either side of the valley, but upland features are not depicted on this map.

The lowest part of the bedrock valley is under the southern end of Onondaga Lake and the city of Syracuse. The bedrock floor of the valley rises southward, to and south of the Tully Moraine, and continues to gradually rise further to the south. The bedrock floor also rises to the north under Onondaga Lake. The thickness of unconsolidated valley-fill deposits along the thalweg of the Onondaga Trough, from Onondaga Lake to the Tully Moraine, averages 420 feet, but near the Tully Moraine it exceeds 800 feet (Kappel and Miller, 2003). 


\section{Bedrock Stratigraphy}

The geologic section of bedrock units along and beneath the Onondaga Trough from Tully to the Onondaga Lake outlet (fig. 5) depicts the approximate bedrocksurface altitude along the thalweg of the Onondaga Trough, the thickness and surface topography of unconsolidated deposits in the valley, the ridgeline profile of the western Onondaga Trough hillside, and the approximate location of bedrock units along the section. The gentle southward dip of the bedrock units, and the southward thickening of the halite beds within the Syracuse Shale is shown graphically, although thin shale beds within the halite unit cannot be shown at the scale of the section.

Bedrock units in central New York are aligned as east-west trending bands. These units dip gently to the south at the rate of 40 to 50 feet per mile. The older (Silurian aged) units underlie the lowlands north of Syracuse, whereas the younger (Devonian aged) units form the hills in the southern part of Onondaga County (fig. 5). The stratigraphic column (fig. 6) summarizes the regional characteristics of the bedrock sequence from the Upper Silurian through Middle Devonian time period, and includes the group and formation names, the lithology, and relative thicknesses of the bedrock units, from the Silurian Lockport Dolomite through the middle Devonian Tully Limestone.

\section{Unconsolidated Stratigraphy}

Geologic sections along and across the Onondaga Trough and some tributary valleys (fig. 7 and sections A-A' through Q-Q') were constructed from hundreds of test holes drilled in the greater Syracuse area. These sections were assembled from data sources that span more than 50 years of varied drilling techniques and sediment interpretations. Therefore, these test-hole logs have been modified, and many have been simplified, to conform to the New York State Geological Survey's lithologic characterization of glacial sediments (Pair, 1998a and b). The stratigraphic units and colors used in these geologic sections follow the nomenclature of the South Onondaga and Otisco Valley quadrangle surficialgeology maps produced through the Statemap program by Pair (1998a and b).

Where possible, modifiers have been added to the lithostratigraphic unit names to indicate their association with a specific landform.

The longitudinal geologic section of unconsolidated sediments along the Onondaga Trough from Tully to the Onondaga Lake outlet is shown in figure 7. This section depicts the layering of sediments deposited generally from south to north during the recession of the glacial ice mass from this part of New York (from 12,000 to 14,000 years ago). This period of recession included pauses and brief readvances of the ice margin in the Onondaga Trough. Interpretation of the geologic data used to create this section during the glacial recession was aided by discussions with Allan Randall (USGS-retired) and Dr. Donald Pair (University of Dayton) who were instrumental in the presentation given in figure 7.
STRATIGRAPHIC COLUMN OF BEDROCK UNITS IN THE ONONDAGA TROUGH

\begin{tabular}{|c|c|c|c|c|c|c|c|}
\hline 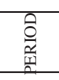 & $\begin{array}{l}\text { Age, in of } \\
\text { millions of } \\
\text { years }\end{array}$ & GROUP & $\begin{array}{l}\text { Bedrock } \\
\text { Symbol }\end{array}$ & \begin{tabular}{|c|}
$\begin{array}{c}\text { FORMATION } \\
\text { Member }\end{array}$ \\
\end{tabular} & LITHOLOGY & \begin{tabular}{|l} 
THICK- \\
NESS \\
(FEET) \\
\end{tabular} & 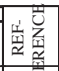 \\
\hline \multirow{9}{*}{ 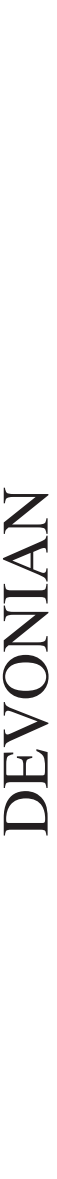 } & \multirow{6}{*}{$\begin{array}{l}\frac{0}{7} \\
\dot{z} \\
\sum\end{array}$} & & & TULLY & Limestone & 30 & \multirow{5}{*}{ 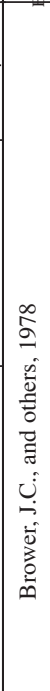 } \\
\hline & & \multirow{4}{*}{ HAMILTON } & \multirow{4}{*}{$\mathrm{Dh}$} & $\begin{array}{l}\text { MOSCOW } \\
\text { Windom }\end{array}$ & Shale and sandstone & 180 & \\
\hline & & & & $\begin{array}{l}\text { LUDLOWVILLE } \\
\quad \text { Portland Point 1s. } \\
\text { Owasco } \\
\text { Spafford } \\
\text { Ivy Point } \\
\text { Otisco } \\
\text { Centerfield ls. }\end{array}$ & Shale and limestone & $\mid \begin{array}{c}10 \\
1-3 \\
25 \\
50-60 \\
16-180 \\
30\end{array}$ & \\
\hline & & & & $\begin{array}{l}\text { SKANEATELES } \\
\text { Butternut } \\
\text { Pompey } \\
\text { Delphi Station } \\
\text { Mottville }\end{array}$ & $\begin{array}{l}\text { Shale and } \\
\text { siltsone }\end{array}$ & $\mid \begin{array}{l}100-200 \\
60 \\
100 \\
45\end{array}$ & \\
\hline & & & & $\begin{array}{l}\text { MARCELLUS } \\
\text { Cardiff } \\
\text { Chittenango } \\
\text { Cherry Valley } \\
\text { Union Springs }\end{array}$ & $\begin{array}{l}\text { Black shale and } \\
\text { limestone }\end{array}$ & $\mid \begin{array}{l}185-200 \\
100 \\
3 \\
13-15\end{array}$ & \\
\hline & & & Don & $\begin{array}{l}\text { ONONDAGA } \\
\text { Seneca } \\
\text { Moorehouse } \\
\text { Nedrow } \\
\text { Edgecliff }\end{array}$ & $\begin{array}{l}\text { Limestone, grey,with } \\
\text { some cherty layers and } \\
\text { one or more bentonite } \\
\text { layers }\end{array}$ & $\begin{array}{l}27 \\
24 \\
14 \\
12\end{array}$ & $\mid \begin{array}{l}4 \\
2 \\
2 \\
\vdots \\
\vdots \\
3 \\
3 \\
0\end{array}$ \\
\hline & \multirow{3}{*}{$\begin{array}{l}\dot{0} \\
0 \\
0 \\
\\
\end{array}$} & TRISTATES & & ORISKANY & Sandstone, white & $0-5$ & ة̈ \\
\hline & & \multirow[t]{2}{*}{ HELDERBERG } & \multirow[t]{2}{*}{ Dhg } & $\begin{array}{l}\text { MANLIUS } \\
\text { Pools Brook } \\
\text { Jamesville } \\
\text { Clarks Reservation } \\
\text { Elmwood } \\
\text { Olney }\end{array}$ & $\begin{array}{l}\text { Limestone and } \\
\text { dolostone, grey/brown }\end{array}$ & $\begin{array}{r}5 \\
16 \\
15 \\
12 \\
40\end{array}$ & 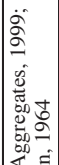 \\
\hline & & & & $\begin{array}{l}\text { RONDOUT } \\
\text { Chrysler }\end{array}$ & Dolostone & 50 & 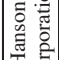 \\
\hline \multirow{6}{*}{ 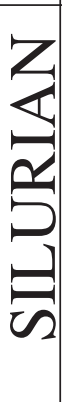 } & \multirow[b]{2}{*}{ 㐫 } & & \multirow[b]{2}{*}{$\mathrm{Scc}$} & COBLESKILL & Limestone & 25 & 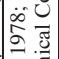 \\
\hline & & BERTIE & & $\begin{array}{l}\text { Oxbow } \\
\text { Forge Hollow } \\
\text { Fiddler s Green }\end{array}$ & $\begin{array}{l}\text { Mostly dolostone with } \\
\text { gypsum layers }\end{array}$ & $\begin{array}{r}9 \\
55 \\
30\end{array}$ & 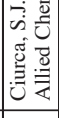 \\
\hline & \multirow[t]{2}{*}{ 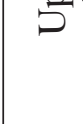 } & \multirow{3}{*}{ SALINA } & \multirow{2}{*}{ Scy } & CAMILLUS & $\begin{array}{l}\text { Shale, trace gypsum, } \\
\text { some Dolomite }\end{array}$ & 250 & 窝 \\
\hline & & & & SYRACUSE & $\begin{array}{l}\text { Shale, halite and trace } \\
\text { gypsum, black }\end{array}$ & 275 & 密 \\
\hline & \multirow[b]{2}{*}{421} & & ${ }^{--} \overline{\mathrm{S}} \overline{\mathrm{v}}-$ & VERNON & Shale, gypsum - green/red & $500-600$ & $\therefore \infty$ \\
\hline & & LOCKPORT & & LOCKPORT & Dolomite, grey & 120-140 & ? \\
\hline
\end{tabular}




\section{GENERALIZED UNCONSOLIDATED DEPOSIT GEOLOGIC SECTION - VALLEY HEADS MORAINE AT TULLY TO ONONDAGA LAKE NEAR SYRACUSE}

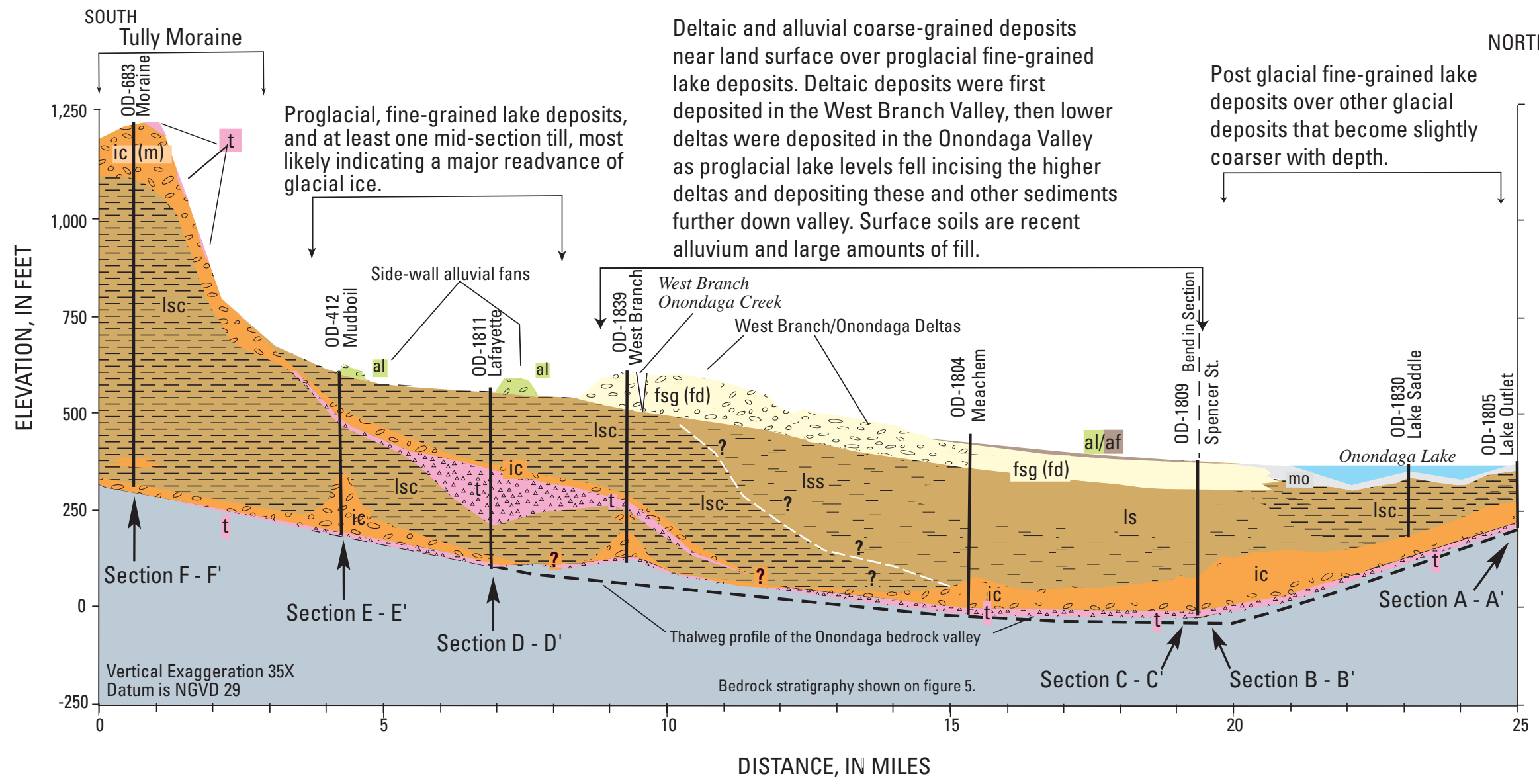

Figure 7. Geologic section along the thalweg of the Onondaga Trough from the Tully Moraine to the Onondaga Lake outlet, showing the generalized layering of unconsolidated sediment in the valley-fill deposits. (Explanation of units shown with geologic section A-A' through $0-0^{\prime}$, see page 8 .) 

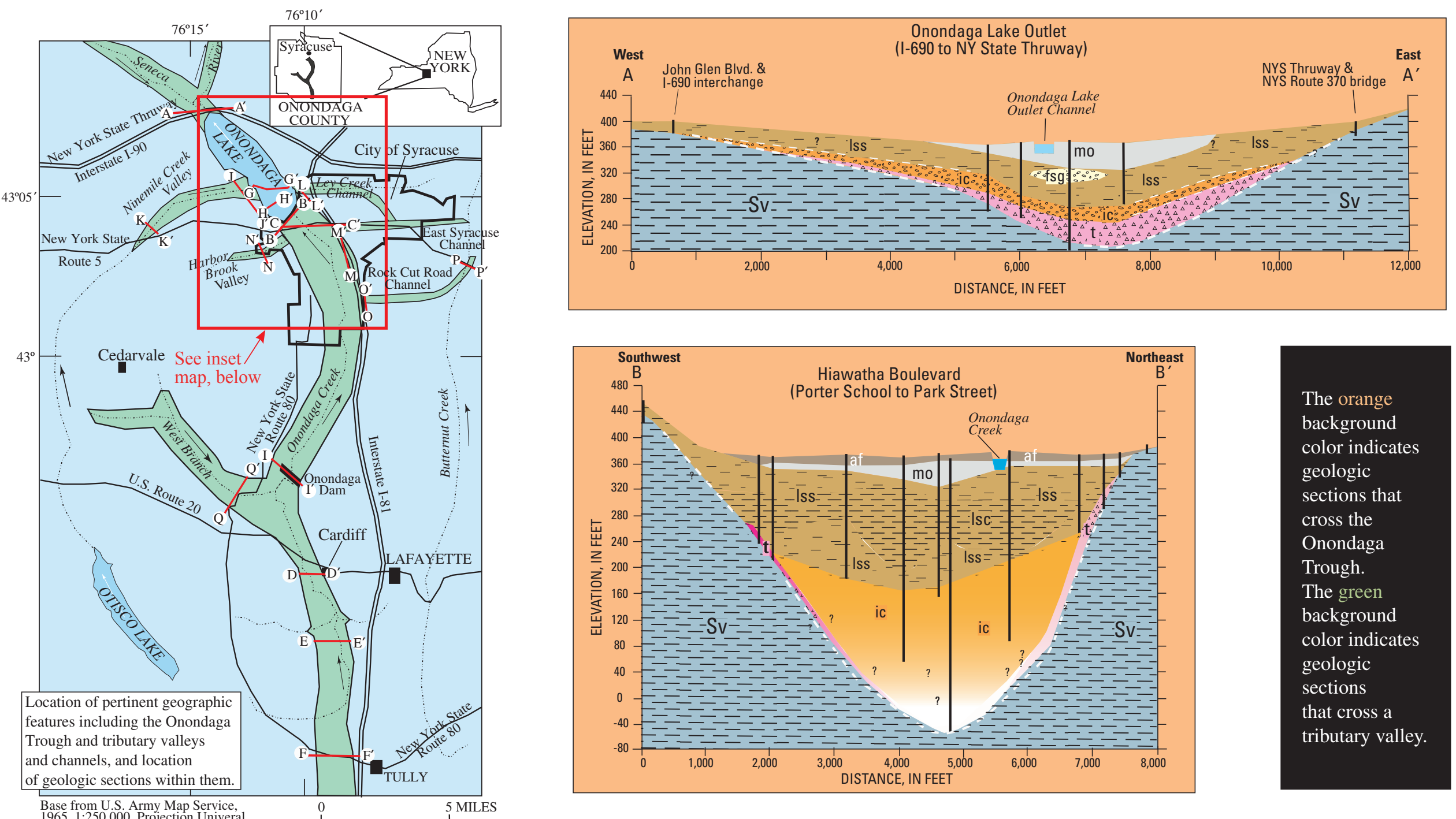

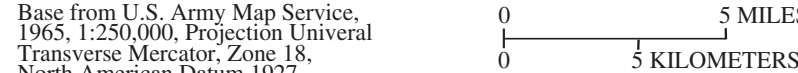
North American Datum 1927.

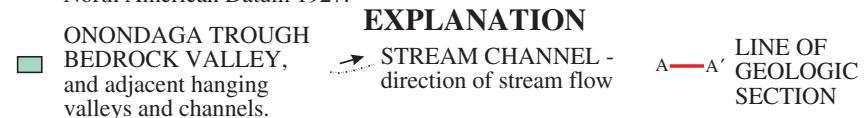
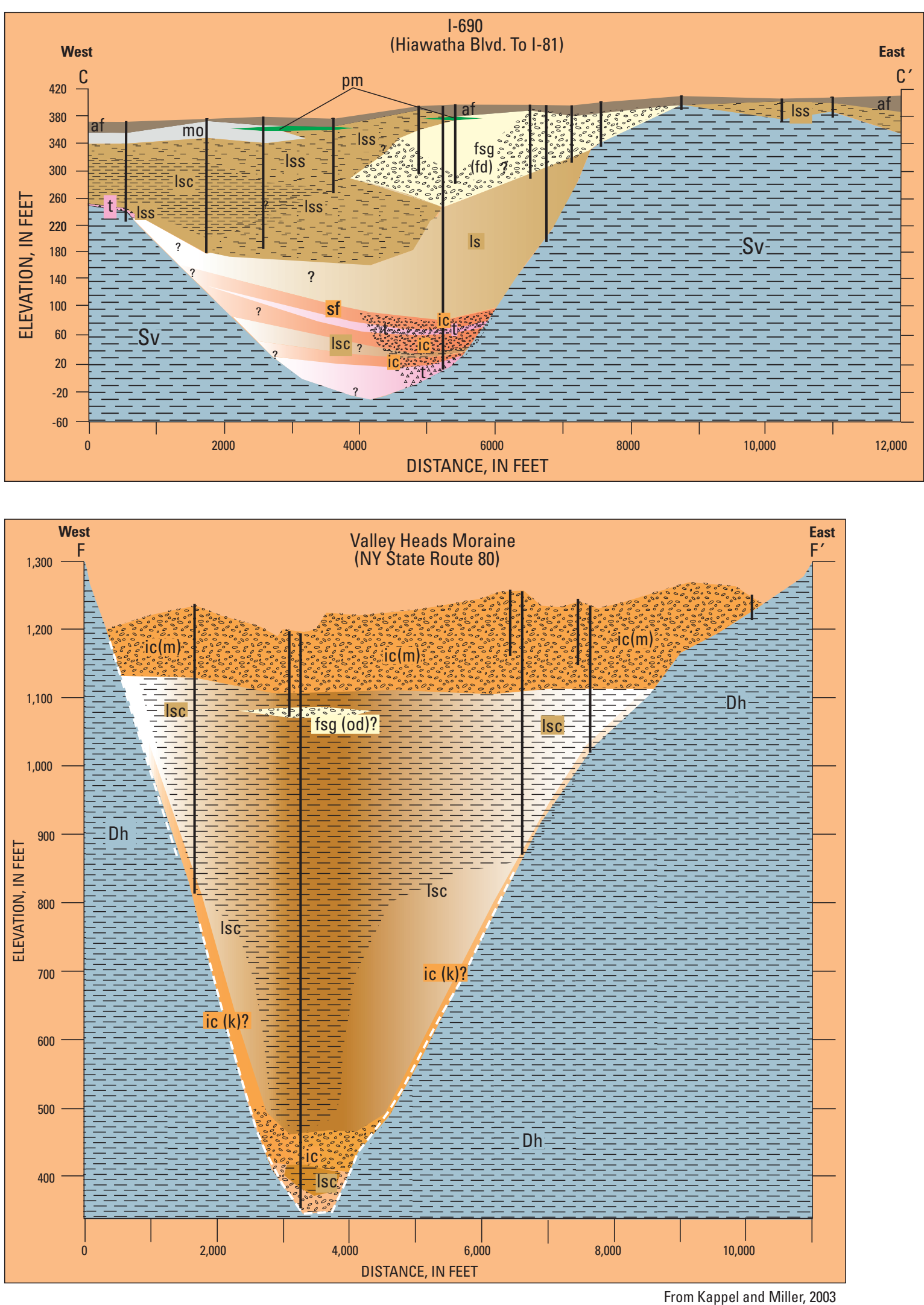
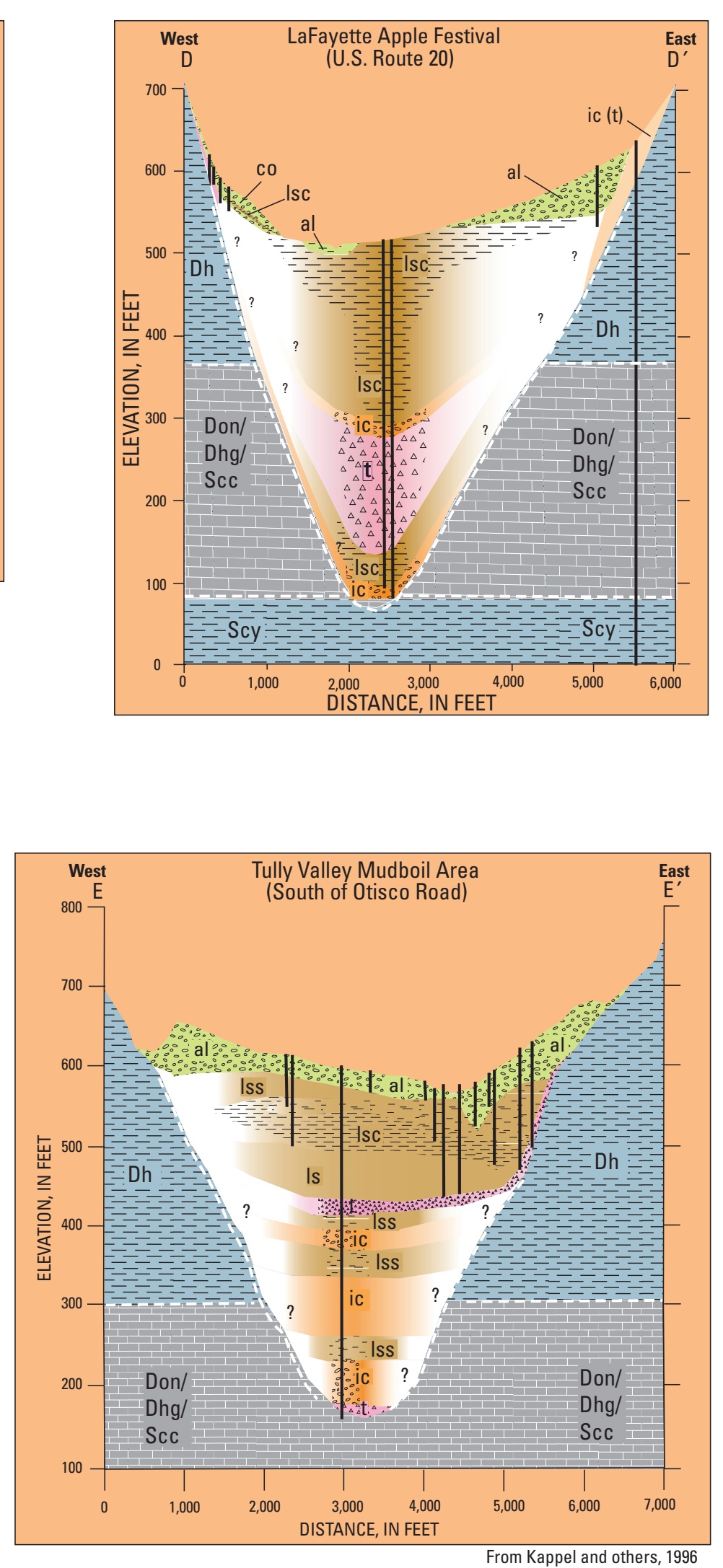

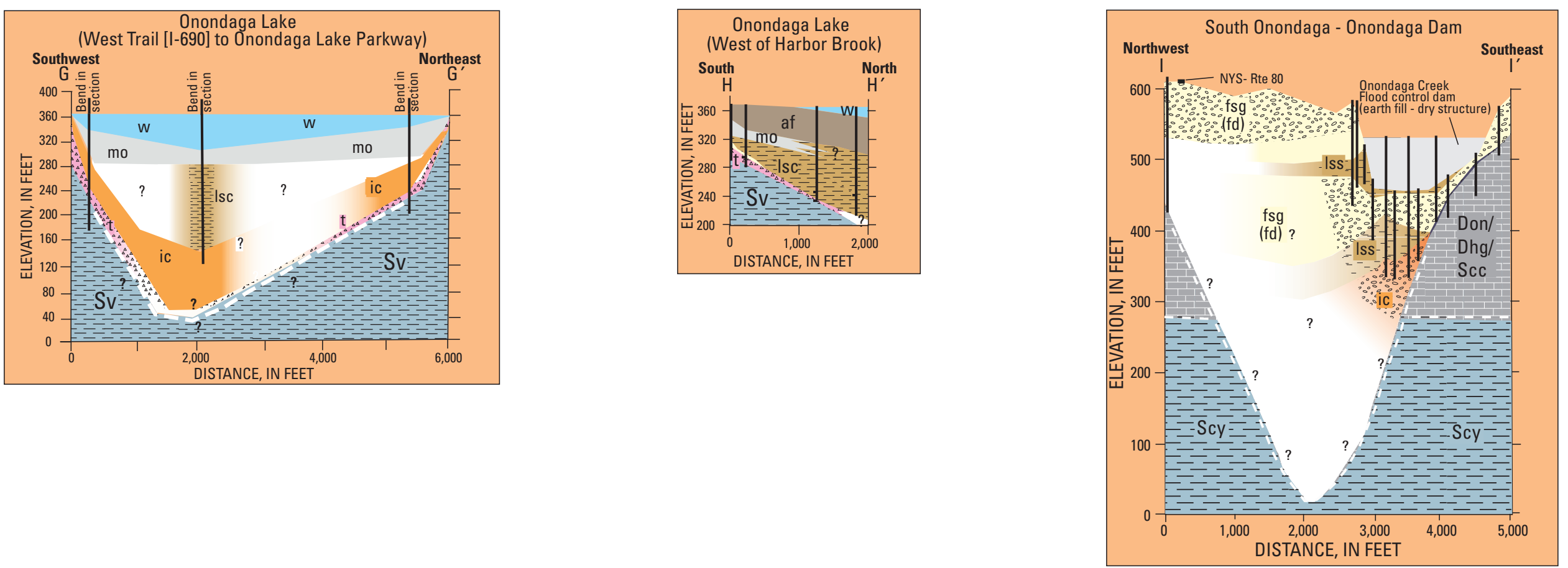

\begin{tabular}{|c|c|c|c|c|c|c|c|c|c|c|c|}
\hline \multicolumn{12}{|c|}{ EXPLANATION } \\
\hline \multicolumn{8}{|c|}{ GLACIAL LITHLOGY AND LANDFORM TYPE } & SEDI & MENT TYPE & \multirow{3}{*}{\multicolumn{2}{|c|}{$\begin{array}{l}\text { Contact between geologic } \\
\text { units, dashed where approximate } \\
\text { Well location } \\
\text { BEDROCK TYPE }\end{array}$}} \\
\hline$-1 \mathrm{sc}=$ & $\begin{array}{l}\text { Lacustrine silt } \\
\text { and clay }\end{array}$ & со & $\begin{array}{l}\text { Colluvium } \\
\text { (Weathered, eroded } \\
\text { bedrock deposits) }\end{array}$ & 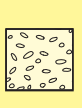 & $\begin{array}{l}\text { Deltaic sand and gravel } \\
\text { discharged from the } \\
\text { West Branch Valley- } \\
\text { Figure } 7 \text { only }\end{array}$ & & Till & & Clay and silt & & \\
\hline $1 \mathrm{ss}$ & $\begin{array}{l}\text { Lacustrine } \\
\text { sand/silt }\end{array}$ & $\mathrm{pm}$ & Peat & & $\begin{array}{l}\text { Subglacial fan } \\
\text { sand and/or gravel }\end{array}$ & af & $\begin{array}{l}\text { Artifical } \\
\text { fill }\end{array}$ & 3 & Silt and sand & & \\
\hline 1s & $\begin{array}{l}\text { Lacustrine } \\
\text { sand }\end{array}$ & 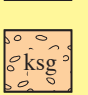 & $\begin{array}{l}\text { Kame end moraine - } \\
\text { sand and gravel }\end{array}$ & id: & $\begin{array}{l}\text { Lacustrine delta } \\
\text { sand and/or gravel }\end{array}$ & $\mathrm{w}$ & Water & & Sand & \begin{tabular}{|c|} 
Shale \\
Bedrock
\end{tabular} & \begin{tabular}{|l|l|} 
& Limestone/ \\
Dolomite \\
Bedrock
\end{tabular} \\
\hline \multirow[t]{2}{*}{ fsg } & \multirow{2}{*}{$\begin{array}{l}\text { Fluvial silt, sand, } \\
\text { and gravel } \\
\text { (op) outwash plain } \\
\text { (od) outwash delta } \\
\text { (fd) fluvio-delta }\end{array}$} & \multirow[t]{2}{*}{ 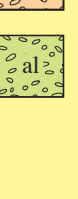 } & \multirow[t]{2}{*}{$\begin{array}{l}\text { Alluvium } \\
\text { (Floodplain, and } \\
\text { aluvial deposits) }\end{array}$} & \multirow[t]{2}{*}{ ic } & \multirow{2}{*}{$\begin{array}{l}\text { Ice contact } \\
\text { sand and gravel } \\
\text { (d) delta } \\
\text { (t) terrace } \\
\text { (k) kame } \\
\text { (m) moraine }\end{array}$} & \multirow[t]{2}{*}{ mo } & \multirow[t]{2}{*}{$\begin{array}{l}\text { Marl \& } \\
\text { Organics }\end{array}$} & & Sand and Gravel & $\begin{array}{l}\text { Dh - Hamilton Group } \\
\text { Scy - Camillus/Syracuse } \\
\text { Sv - Vernon }\end{array}$ & $\begin{array}{l}\text { Don - Onondaga } \\
\text { Dhg - Helderberg Group } \\
\text { Scc - Bertie }\end{array}$ \\
\hline & & & & & & & & & Boulders & $\begin{array}{l}\text { Vertical Exaggeratio } \\
\text { Datum is NGVD } 29\end{array}$ & $10 x--$ all sections \\
\hline
\end{tabular}
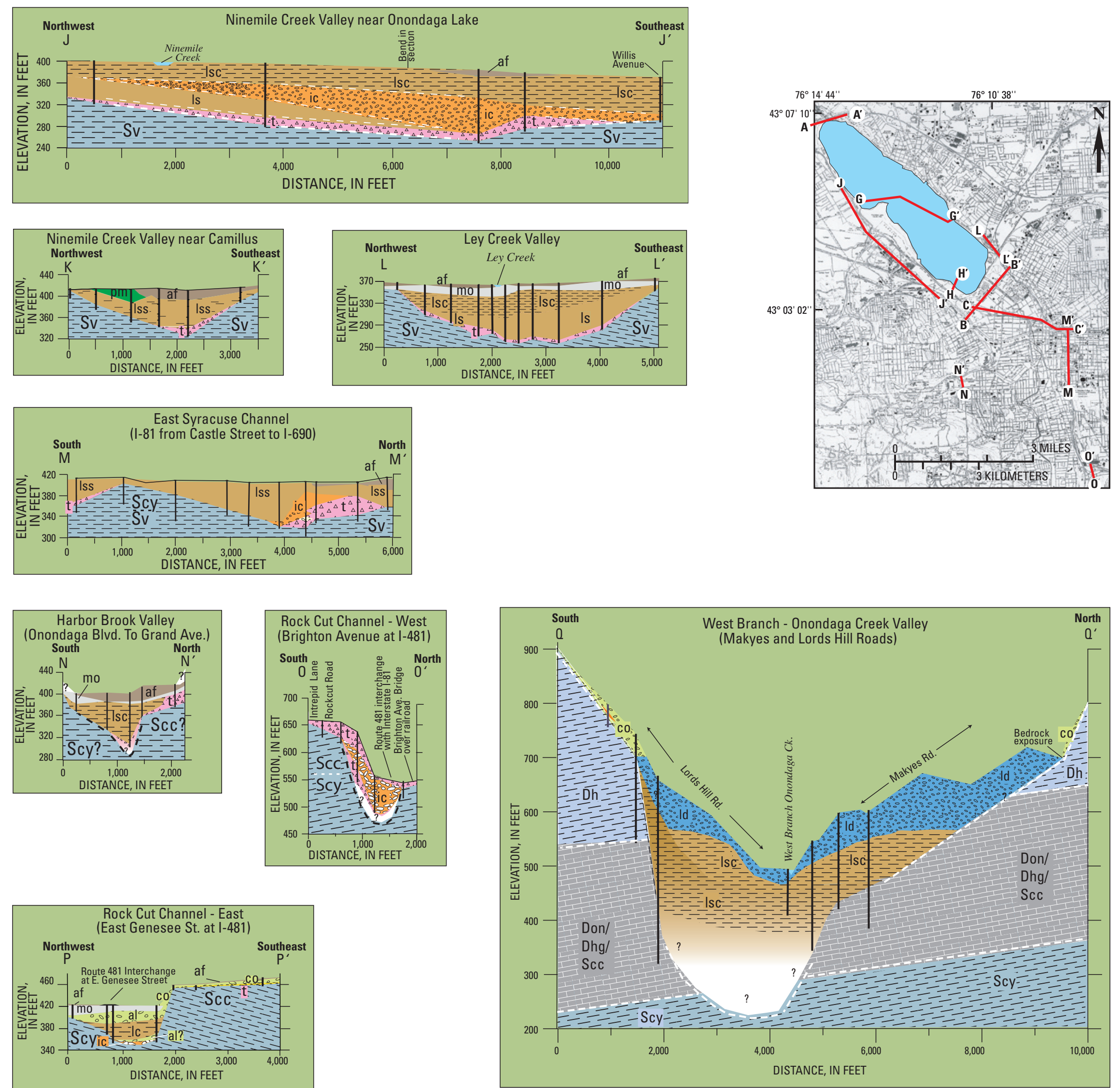


\section{Source of the Brine}

The brine found in the Onondaga valley-fill aquifer could be derived from either (1) the dissolution of local halite (rock salt) beds found in the Syracuse Shale south of the city, or (2) from deeper bedrock formations below the Lockport Dolomite (figs. 5 and 6) in the Appalachian Basin of New York, Pennsylvania, and eastern Ohio. Water-quality samples were taken from test holes drilled for the USGS to the base of the Onondaga Trough (approximately 420 feet deep) to determine the source of the brine. The brine samples were tested for major ion concentrations as well as stable isotope concentrations. Results of these analyses were consistent with salinity from rock salt (dissolution of local halite beds) rather than salinity contributed by (regional) Appalachian Basin formation waters (Baldauf, 2003). This finding is encouraging because brine derived from halite dissolution contains mainly sodium chloride with minor amounts of heavy metals, whereas deep-basin brines have high concentrations of metals that could impair water quality in the lake.
A plot of chloride concentration as a function of sodium concentration in brine samples from different sources in the Onondaga Trough is shown in figure 8 . These sources are artesian-pressured springs and mudboils in the southern end of the valley (Kappel, 1996), and 19th century data from brine springs and deep brine wells near Onondaga Lake, which are compared with average seawater and a composite of Appalachian Basin brine samples (Siegel and others, 1990). All samples except the Appalachian Basin brine fall along the halite-dissolution line, supporting the thesis that the Onondaga Trough brine is not from an Appalachian Basin source (Baldauf, 2003). A plot of bromide concentration as a function of chloride concentration in samples from deep USGS wells and Appalachian Basin brine (fig. 9) indicates that the Appalachian brine is typically enriched with bromide, whereas the Onondaga Trough brine contains negligible bromide concentrations.

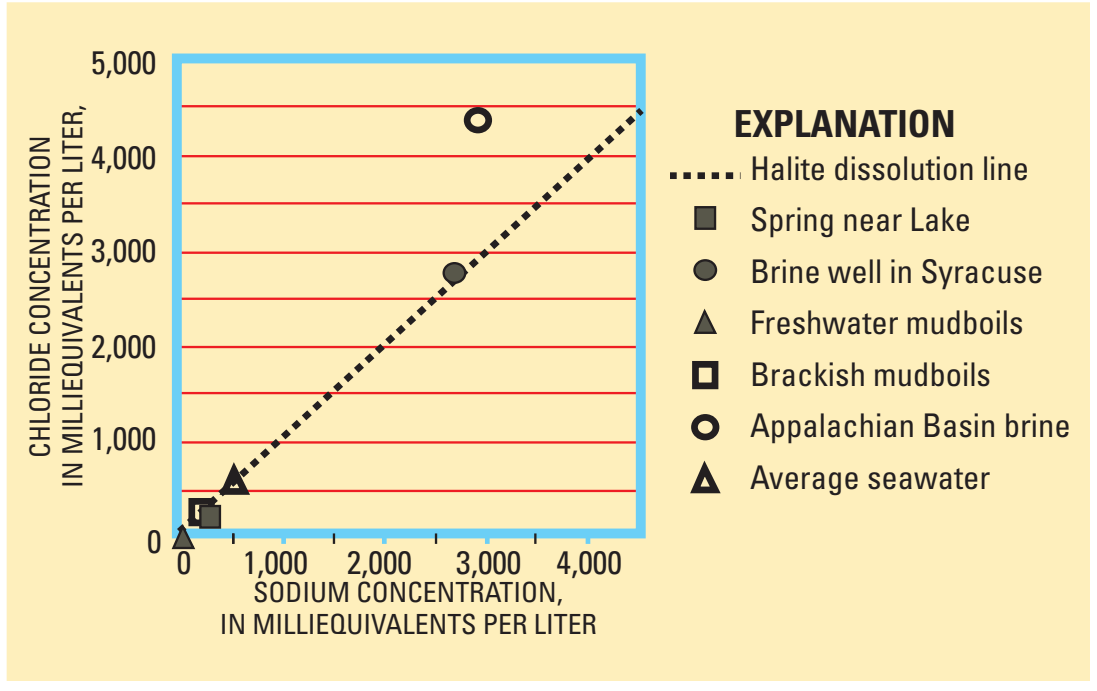

Figure 8. Chloride concentration as a function of sodium concentration in brine from historic and current Onondaga Valley datasets. (Data from Baldauf, 2003, fig. 14).

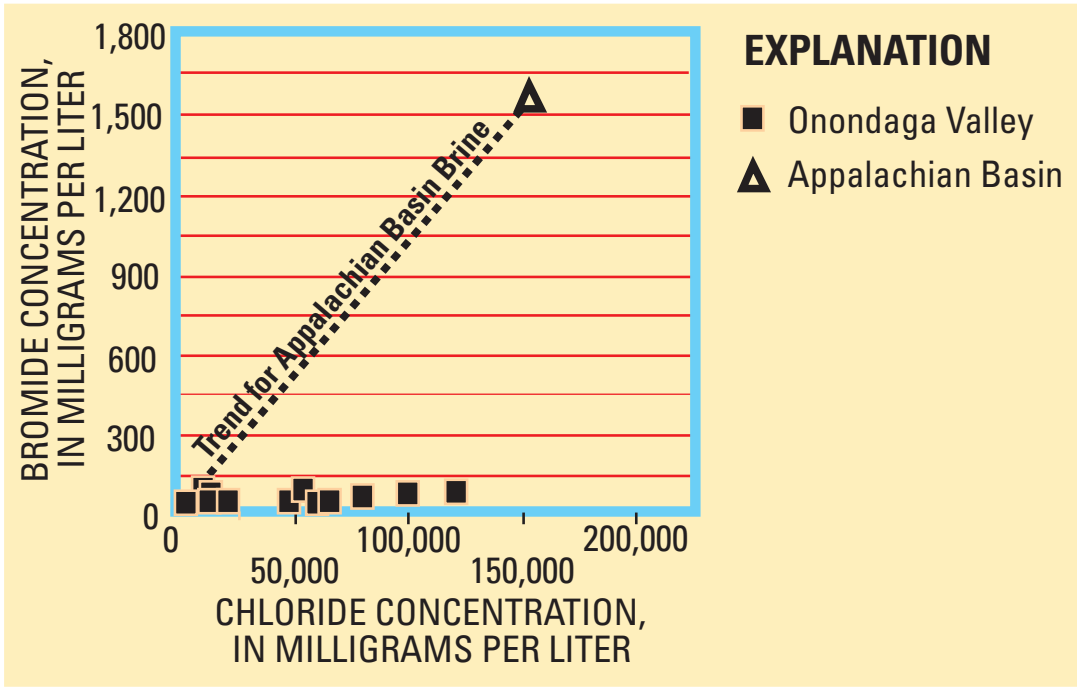

Figure 9. Bromide concentration as a function of chloride concentration in brine from U.S. Geological Survey test holes installed in the Onondaga Valley during the summer of 2002 (Data from Baldauf, 2003, fig. 19). 
A plot of strontium concentration as a function of calcium concentration in USGS well samples (fig. 10) shows the trend line for the Onondaga Trough samples to be slightly steeper than the trend line for Appalachian Basin samples, further differentiating the two sources of the brine. A plot of the isotopic content of deuterium (D) as a function of oxygen-18 (180) in brine samples from Onondaga Trough wells and Appalachian Basin brine is given in figure 11. The "light" isotope values from the Onondaga Trough wells cluster around the "local" meteoric water line that represents recharge water from local (recent) sources, the "heavier" isotopic signal represents deeper, older, and more distant Appalachian Basin water.

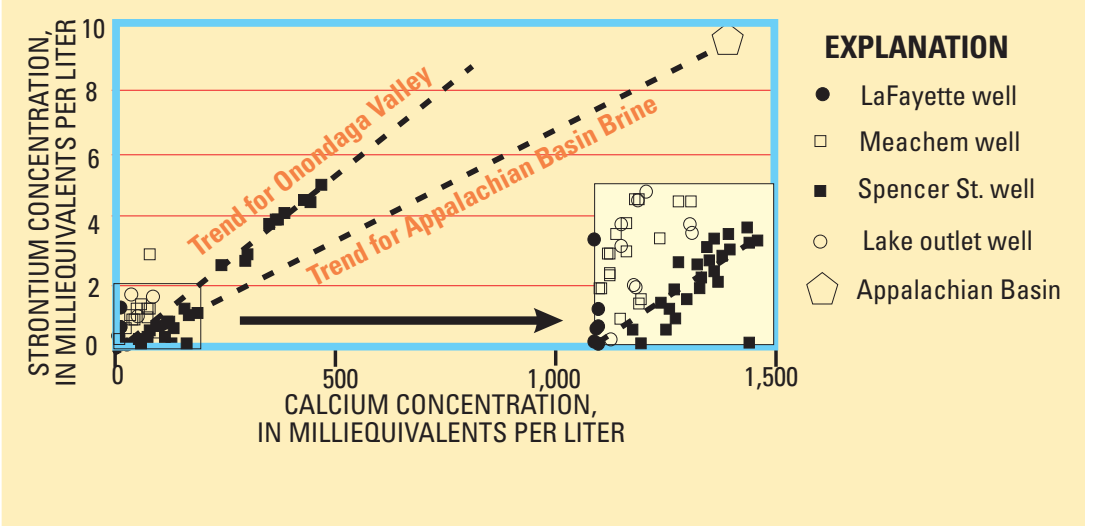

Figure 10. Strontium concentration as a function of calcium concentration of unconsolidated-sediment matrix water from U.S. Geological Survey test holes drilled in the Onondaga valley during the summer of 2002 (Data from Baldauf, 2003, fig. 18).

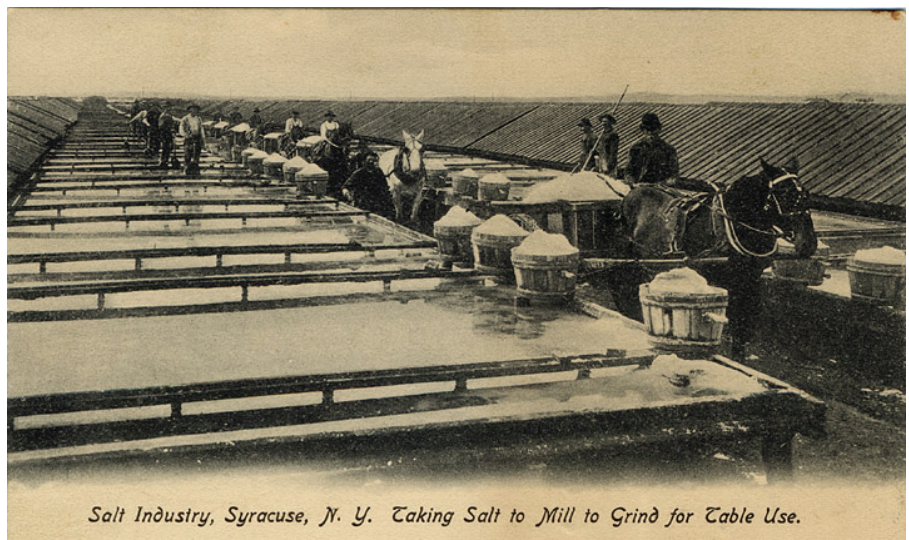

Salt Indusiry, Syracuse, N. Y. Taking Salt to Mill to Grind for Zable Use.

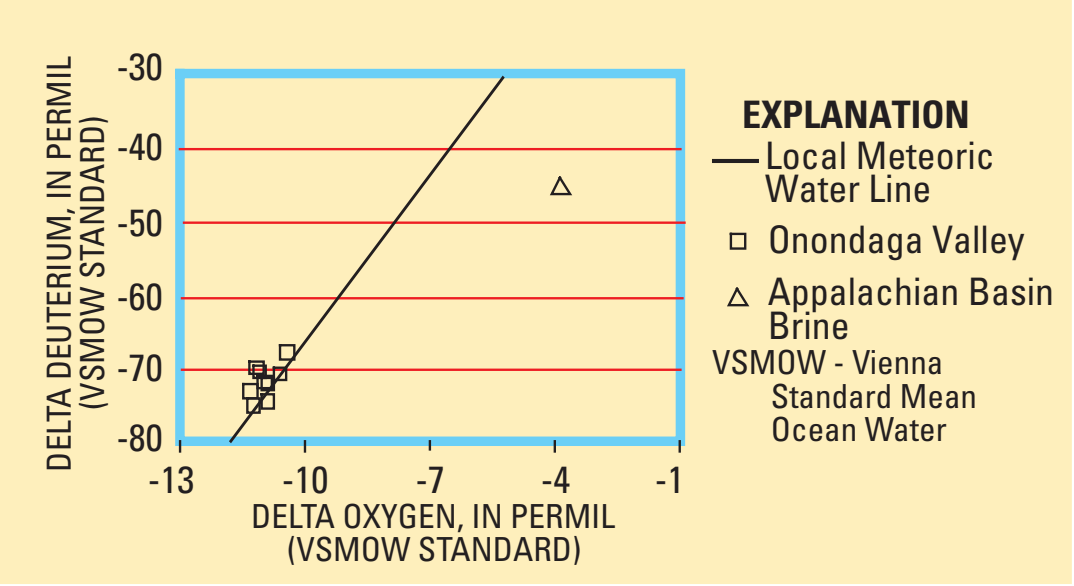

Figure 11. Deuterium (D) and Oxygen-18 (180) content of brine samples collected from U.S. Geological Survey test holes during the summer of 2002. (Data from Baldauf, 2003, fig. 21, Syracuse area meteoric water line developed by Dr. Henry Mullins, Syracuse University). 


\section{Brine Concentrations in the Onondaga Valley-Fill Aquifer}

Preliminary analysis of water samples collected from deep wells throughout the Onondaga valley-fill aquifer indicate that the brine tends to increase in concentration toward the northern end of the aquifer near Onondaga Lake. At present, brine concentrations are highest near the outlet of the lake and in the lower sections of the Ninemile Creek tributary valley (fig. 12), rather than in the deepest part of the aquifer beneath and south of the southern end of the lake (fig. 4), where the densest (heaviest) brine would normally settle.

Historical records of brine concentrations from wells drilled for the production of salt during the mid-19th century indicate that, when the deepest wells were drilled, the most-concentrated brine was about 80-percent saturated (Kappel, 2000), or about six times as salty as seawater. This brine would yield about 2.0 pounds of salt from every gallon of brine withdrawn from the aquifer. After 5-6 decades of pumping, the concentrations had decreased to about 60-percent saturation - about four times as salty as seawater (Kappel, 2000) or about 1.5 pounds of salt per gallon of brine. Because these wells were located near the southern end of the lake, the lower brine concentrations seen today in deep wells in this area (Lake Inlet and Spencer St. wells, fig. 12) may indicate that the most concentrated brines had been extracted from the aquifer by the end of the 19th century. The higher concentrations seen today (2004) near the lake outlet and near the outlet of the Ninemile Creek valley may be remnant concentrations of brine still trapped within this part of the aquifer.

Ground water along the Seneca River upstream of the lake outlet in 2003 was fresh (having low dissolved-solids concentrations), as indicated by samples from a test well drilled at the Baldwinsville wastewater-treatment plant (WWTP), where depth to bedrock was only 46 feet. A similar test well was drilled along the Seneca River at the Wetzel Road WWTP (fig. 12), downstream from the lake outlet. Depth to bedrock at this location was 104 feet, and the water was brine. This difference in water quality is attributed to (1) the configuration of the Seneca River channel - shallow bedrock upstream from the lake outlet and deeper bedrock downstream; (2) the northward direction of flow in the river - from Baldwinsville toward Wetzel Road, and (3) the presence of strong brine in the lake outlet area that naturally flowed into the deeper part of the Seneca River bedrock valley. The salty water that is found in the bedrock further north, near Lake Ontario, is assumed to be a deep-basin brine flowing slowly northward through the Vernon Shale, the Lockport Dolomite, and deeper bedrock units (Kantrowitz, 1970).

\section{Salinity as Seawater Equivalent}

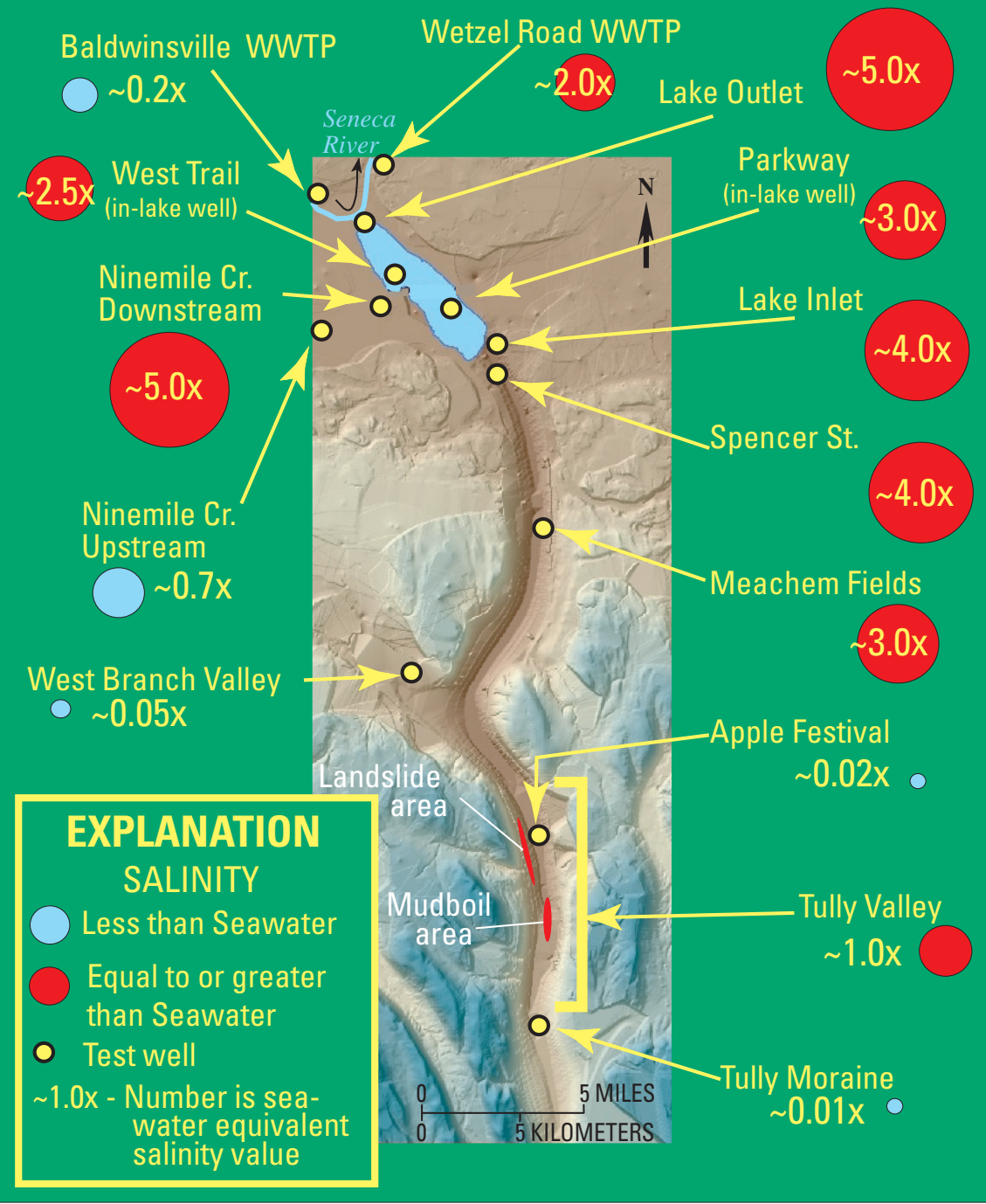

Figure 12. Locations of test holes drilled to bedrock in the Onondaga, Ninemile Creek, and Seneca River valleys in 2002-03 and the results of salinity analyses, as expressed in seawater-equivalent values. 
Two wells were drilled offshore in Onondaga Lake during the summer of 2003 (Parkway and West Trail sites) as part of this study. These wells were drilled nearly 400 feet from shore and penetrated more than 100 feet of unconsolidated sediment before entering the Vernon Shale. The water in each well was about 2.5 times as salty as seawater, even at these shallow depths in the valley-fill aquifer.

A test hole was drilled 189 feet to reach bedrock in the Ninemile Creek tributary valley, just downstream from the village of

Camillus. Water from the bedrock was saline (70 percent as salty as sea water), and the source of the salty water was probably ground water flowing up dip (northward) through bedding-plane fractures in the Vernon Shale. A test hole drilled within a calcium-chloriderich industrial wastebed area, close to Onondaga Lake, penetrated bedrock at 135 feet and the water was a concentrated brine. The source of this water was probably remnant valley-fill aquifer brine that was unaffected by the pumping of brine at the southern end of the lake during the middle-to-late 1800's.

Salinity in the southern part of the Onondaga Trough (the Tully Valley) is variable. Water at the Tully Moraine is fresh, at a depth of 730 feet below land surface. Whereas further north, the water ranges from fresh to nearly brackish (about 20 percent as salty as seawater) in flowing wells and in springs that discharge on the valley floor in and around the Tully Valley mudboil area (fig. 12). Springs along the western flank of the valley that discharge within four landslide areas north of the mudboil area, range from fresh to saline. A 380-foot-deep domestic well along the valley floor in this area discharges saline water, whereas just to the north, a 420-foot deep test well (Apple Festival, fig. 12) and some 250-foot-deep domestic wells arrayed across the valley floor discharge water that is generally fresh. All of these wells are artesian-pressured, having hydraulic heads (water levels) tens of feet above land surface. Finegrained sediments most likely confine the valley-fill aquifer in this part of the valley, causing artesian pressures and limiting the flow of ground water northward into the northern part of the valley-fill aquifer. Brackish to saline water discharging from springs and wells in the Tully Valley enters Onondaga Creek, but this water is diluted by the volume of freshwater flowing in the creek.

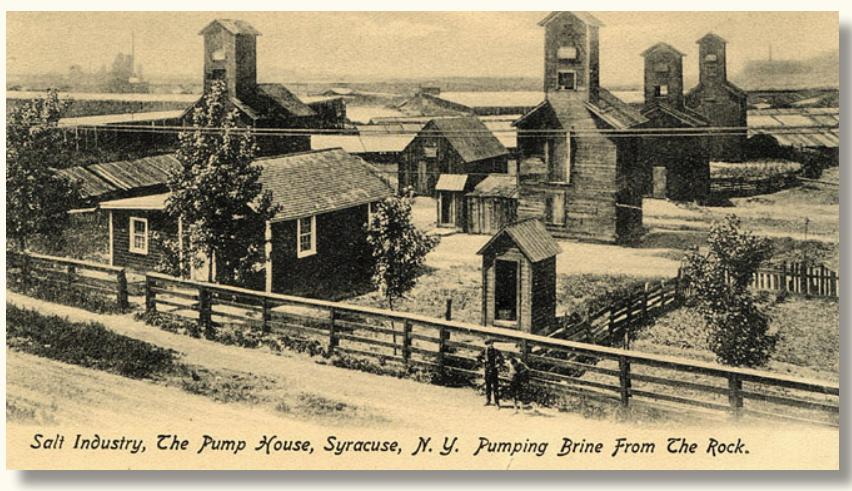

\section{Summary}

Efforts to improve water quality in Onondaga Lake, N.Y. and its tributaries require an understanding of how the natural, brine-filled aquifer in the Onondaga Trough affects the freshwater in Onondaga Lake. Little was known about the source of the brine, its movement within the glacial sediments (valley-fill aquifer) that partly fill the Onondaga Trough, and the interaction of the aquifer and the lake. Initial data-collection and analysis efforts by the U.S. Geological Survey in the 25-mile long Onondaga Trough indicate that (1) the trough is deepest near the city of Syracuse and under the southern end of Onondaga Lake, (2) the brine was formed naturally by the dissolution of halite deposits in the bedrock which lie to the south of Syracuse, and (3) the concentration of the brine is highest under the central and northern part of the valley-fill aquifer. All of the geologic and water-quality data collected to date will be used in the development of a mathematical model of ground-water flow in the valley-fill aquifer that will assist others to improve water quality in Onondaga Lake. 


\section{Selected References}

Allied Chemical Corporation, Solvay Process Division, 1964, Brine section-brine supply Tully [bedrock] Stratigraphy: Syracuse, N.Y., pl. no. 94129-1.

Baldauf, A.C., 2003, The origin of Onondaga Valley brines - a geochemical investigation: Syracuse, N.Y., State University of New York - School of Environmental Science and Forestry, M.S. thesis, 61 p., 3 appendixes.

Brower, J.C., Nye, O.B., Jr., Belak, R., and others, 1978, Faunal assemblages in the lower Hamilton Group in Onondaga County; in, Merriam, D.F., ed., New York State Geological Association Fieldtrip Guidebook: Syracuse, N.Y., p. 104-142.

C\&S Engineers Inc., and H\&A of New York, 1992, A projection of future geologic conditions in the Tully Valley, Onondaga County, New York: Syracuse, N.Y., [prepared for Allied Signal. Inc.], 35 p.

Ciurca, S.J., 1978, Eurypterid horizons and stratigraphy of upper Silurian and Lower Devonian rocks of central-eastern New York state; in, Merriam, D. F., ed. Syracuse, N.Y., New York State Geological Association Fieldtrip Guidebook, p. 225-249.

Hand, B.M., 1978, The Syracuse meltwater channels; in, Merriam, D. F., ed., New York State Geological Association Fieldtrip Guidebook: Syracuse, N.Y., p. 286-314.

Hanson Aggregates East, Inc., 1999, Generalized geologic columnar section Jamesville Quarry: Jamesville, N.Y., 1 pl.

Kantrowitz, I.H., 1970, Ground-water resources of the eastern Oswego River Basin, New York: New York State Conservation Department, Water Resources Commission, Basin Planning Report ORB-2, 129 p.
Kappel, W.M., 2000, Salt production in Syracuse, New York ("the salt city") and the hydrogeology of the Onondaga Creek valley: U.S. Geological Survey Fact Sheet FS 139-00, 8 p.

Kappel, W.M., and Miller, T.S., 2003, Hydrogeology of the Tully trough: U.S. Geological Survey Water-Resources Investigation Report 03-4112, 16 p.

Kappel, W.M., Sherwood, D.A., and Johnston, W.H., 1996, Hydrogeology of the Tully Valley and characterization of mudboil activity, Onondaga County, New York: U.S. Geological Survey Water-Resources Investigations Report 96-4043, $71 \mathrm{p}$.

Oliver, W.J., Jr., 1954, Stratigraphy of the Onondaga limestone (Devonian) in central New York: Bulletin of the Geological Society of America, v. 65, p. 621652.

Pair, D.L., 1998a, The Surficial Geology of Otisco Valley, NY (7.5-minute) Quadrangle: United States Geological Survey-New York State Geological Survey Map no. 2gk1234, scale 1:24,000.

Pair, D.L., 1998b, The Surficial Geology of Tully, NY (7.5-minute) Quadrangle: United States Geological Survey-New York State Geological Survey Map no. $2 \mathrm{gk} 1236$, scale 1:24,000.

Siegel, D.I., Szustakowski, R.J., and Frape, Shawn, 1990, Regional appraisal of brine chemistry in the Albion Group sandstones (Silurian) of New York, Pennsylvania, and Ohio: Association of Petroleum Geochemical Explorationists, Bulletin no. 6, p. 66-77.

Winkley, S.J., 1989, The hydrogeology of Onondaga County: Syracuse, N.Y., Syracuse University, Department of Geology, M.S. thesis, 171 p. 
For additional information about this report write to:

U.S. Geological Survey

30 Brown Road

Ithaca, NY 14850

Email: askny@usgs.gov

World Wide Web: http://ny.usgs.gov/
For sale by

U.S. Geological Survey, Information Services

Box 25286, Denver Federal Center

Denver, CO 80225

For more information about the USGS and its products: Telephone: 1-888-ASK-USGS

World Wide Web: http://www.usgs.gov/

\section{$\star{ }^{\star}+125_{\text {years of }}^{\star}$}

$-\star$ 